\title{
Stakeholders' Pressure and CSR Engagement. A Case in the Apparel Sector
}

\author{
Andrea Lucchini, Anna Maria Moisello \\ Department of Economics and Management, University of Pavia, Pavia, Italy \\ Email: annamaria.moisello@unipv.it
}

How to cite this paper: Lucchini, A. and Moisello, A.M. (2019) Stakeholders' Pressure and CSR Engagement. A Case in the Apparel Sector. American Journal of Industrial and Business Management, 9, 169-190.

https://doi.org/10.4236/ajibm.2019.91012

Received: December 8, 2018

Accepted: January 13, 2019

Published: January 16, 2019

Copyright $\odot 2019$ by authors and Scientific Research Publishing Inc. This work is licensed under the Creative Commons Attribution International License (CC BY 4.0).

http://creativecommons.org/licenses/by/4.0/

\begin{abstract}
This paper, drawing on stakeholder and legitimacy theory, addresses the issue of stakeholders' pressure effect on a firm's CSR behavior. It focuses on the apparel sector as these companies, characterized by consumer proximity, are under the lens of stakeholders for their direct social performance as well as for their suppliers' actions. We analyze the Nike case in order to study how stakeholders' pressure shapes a firm's engagement in CSR issues. Our study points out the dynamic nature of stakeholders and legitimacy, and it underlines the influence of two actors which are rarely considered as primary and most important stakeholders, namely media and social activist groups.
\end{abstract}

\section{Keywords}

Corporate Social Responsibility, Stakeholders' Pressure, Stakeholders Theory, Legitimacy, Nike

\section{Introduction}

Societal expectations about corporate activities nowadays focus on firms' economic responsibilities within the boundaries established by law as well as within ethical guidelines. As Buchholtz and Carroll [1] observed "the social responsibility of business encompasses the economic, legal, ethical, and discretionary (philanthropic) expectations that society has of organizations at a given point in time". If a firm does not comply with these expectations, society, and more specifically corporate stakeholders are likely to withdraw their support and the legitimacy that allows companies to survive [2].

Empirical studies demonstrate that a firm's CSR activities affect its consumers purchasing behavior [3]. CSR commitment shapes a company's image and by this means the overall product evaluation [4] because environmental and social responsibility provides a relevant repositioning opportunity as it creates shared 
value.

Environmental-sensitive industries are more subject to a legitimacy gap caused by their direct actions, but CSR concerns also take into account issues, such as child labor and sweatshops, which can affect many industries [5]. Stakeholders are very sensible not only to a firm's direct actions but also to its suppliers' behavior [5]; therefore firms engage with stakeholders' pressures caused both from their direct and indirect actions.

This paper, drawing on stakeholder and legitimacy theory, studies the behaviour of companies in the apparel sector in terms of their answer to stakeholders' pressures. Apparel companies have been, and continue to be, strongly criticized about their poor performance in social issues, as demonstrated by the very recent articles published by Financial Times [6] and New York Times [7]. These criticisms are related to activities performed both inside their factories and in those owned by their suppliers, which have been termed as sweatshops. This brought the sector under the length of societal scrutiny, thus forcing companies to adopt measures in order to re-establish legitimacy.

According to legitimacy theory, a company has to operate following societal expectations. If this does not happen, a legitimacy gap is likely to arise, eventually leading to the withdrawal of company's legitimacy, thus threatening its survival. In order to avoid this situation, a company has to show that it is operating in line with social values and beliefs. The stakeholder theory helps to understand to whom the corporations have to account. When companies take decisions, they have to take into account not only the interest of their shareholders, but also those from other stakeholders. In fact, focusing only on shareholders' interests may threaten corporate's legitimacy and thus the continual of its operations.

Media and social activist groups are increasing their power in influencing corporates' decisions, both because they rise and unify the voice of other stakeholders, and because they disclose all corporates' operations, thus pressuring companies in operating in a socially responsible way.

In order to test these assumptions, we analyse the Nike case. This case is of interest as Nike is one of the more visible companies in the apparel sector and it had to face great pressures from its stakeholders to behave more ethically and it has recently experienced a new wave of anti-sweatshop protests [8] [9] [10]. This study is made through the adoption of the stakeholder network theory during three different period of Nike's activity, thus allowing to catch the dynamic nature of legitimacy and of the stakeholders' concept and attributes.

\section{The Theoretical Framework: Stakeholder and Legitimacy Theory}

\subsection{Stakeholder Theory}

The concept of stakeholders has become popular since the publication of the book Strategic Management: A Stakeholder Approach [11].

By the years, stakeholder theory has gone to challenge the main idea of that 
time: the so called "shareholder theory", which represents the point of view of the neoclassical economists, which main proponent is Milton Friedman. While the first theory talks about the duty of a company to engage in a positive relationship with all its stakeholders, the latter has the only objective of profit maximization, taking into account just the shareholders' interests. Stakeholders are defined as "any group or individual who can affect or is affected by the achievement of the organization's objective" [11]. Mitchell et al. [12] enter in a concrete field, explaining how managers should decide the degree of attention to dedicate to each stakeholder. In order of doing so, they assigned to stakeholders three attributes: legitimacy, power, and urgency. Legitimacy is the most important attribute for those scholars who look for a "normative core" for the stakeholder theory and refers to the "perceived validity or appropriateness of a stakeholder's claim to a stake" [12]. According to these customers, employees and shareowners have a high degree of legitimacy, competitors and media have surely a lower one, and government somewhere in the middle according to the social and political ideology of the country of reference. Power is the "ability or capacity to produce an effect-to get something done that otherwise may not be done" [12]. It is important to note that power and legitimacy are distinct, so they can exist independently or be combined to create authority. The third attribute is urgency, defined as "the degree to which the stakeholder claim demands immediate attention" [12]. It follows that urgency exists when: "a relationship or claim is of a time-sensitive nature" and when "that relationship or claim is important or critical to the stakeholder" [12].

Stakeholder theory points out that society is not a homogeneous group of individuals with identical expectations but is made up of different groups that have different expectations about a firm's actions and a varying ability to influence its behavior [13]. The concept of stakeholders relates to the inter-relationship between the firm and different groups of individuals, i.e., shareholders, employees, suppliers, customers, environment and community. Firms try to adapt their actions to the values of their stakeholders [14]; they try to manage the relationship with their key stakeholders and change their perceptions disclosing their CSR behavior [13] [15]. Legitimacy and Stakeholder theories are two perspectives of the issue and Stakeholder theory offers relevant suggestions in order to identify what groups of stakeholders might have an important influence on a firm's durability, and it focuses the expectations to be met [16].

\subsection{Legitimacy Theory}

Legitimacy theory is, along with the stakeholder theory, one of the most used theory in order to analyse the behaviour of a company dealing with corporate social responsibility.

Suchman [17] stated that "legitimacy is a generalized perception or assumption that the actions of an entity are desirable, proper, or appropriate within some socially constructed systems of norms, values, beliefs, and definitions". Le- 
gitimacy is therefore something that companies cannot assign to themselves, on the contrary they have to act according to a set of beliefs and values that are established by the society, in order to be perceived as legitimate. Moreover, it appears clear that legitimacy is something that companies may have today, but they may have not in the future if they fail to keep a behaviour in compliance with society's values and beliefs, which in turn are subjects to continuous changes. Finally, organizations may retain legitimacy although they depart from societal values if this is perceived as unique or go unnoticed. In fact, as the definition stated, legitimacy is a perception or assumption. However, societal values and beliefs is such a broad term that risk becoming too complicated and vague for managers to deal with it and can mislead the idea behind CSR. Corporations do not have to answer and be accounted for every social problem, but just those related to their stakeholders [18] [19]. In this way, it is possible to relieve companies to the duty of following the expectations of non-legitimate stakeholders, such as terrorist organizations and of society in general. For example, solving illiteracy may reasonably be considered a socially acceptable behaviour by the society, but this issue can't fall in the category of corporate responsibility. It has to be considered as a social issue, not as a stakeholder issue. That said, a company may decide to face this problem in any case, but it follows manager's evaluation which has nothing to do with maintaining the legitimacy in front of its stakeholders. In fact, an apparel company operating in a Third World country may decide to deal with the illiteracy problem because it is judged as influencing negatively the productivity of the workers, and therefore the profitability of the company. Wood too highlighted this issue, saying that "stakeholder analysis provided a starting point for scholars to think about how society grants and takes away corporate legitimacy", specifying that "if central stakeholders lose confidence in the firm's performance, legitimacy may be withdrawn" [19]. A company needs to understand stakeholders' expectations as central stakeholders may decide to revoke the legitimacy.

According to Suchman [17], three kinds of legitimacy do exist: pragmatic, moral and cognitive. Pragmatic legitimacy, results from the self-interested calculation made by company's stakeholders. They will concede legitimacy to the organizations as long as they perceive that they will benefit from corporate's activities [20]. Therefore, the corporation has to attempt to influence the stakeholders and persuade them about the usefulness of its activities. This can be done through stakeholders' involvement in corporate decision-making and through a careful management of public relations and communication. In the apparel sector, a sort of pragmatic legitimacy is given to unethical companies by some customers, which tend to justify, or at least not to critic, those companies involved in sweatshops scandals as long as they receive the benefit of lower prices. Moral legitimacy, it rests not on self-interest calculation but rather on "positive normative evaluation of the organization and its activities" [17] (p. 579). Thus, these judgements are based on the effective evaluation of corporate's ac- 
tivities and are expected to be resistant to firm's attempts to manipulate and influence stakeholders in the evaluation process. Stakeholders judge an organization as legitimate if "socially acceptable goals in a socially acceptable manner" are pursued [21]. The company has, therefore, to actively and honestly involve stakeholders and adopt full transparency in the communicative process, without attempting of greenwashing. Cognitive legitimacy emerges when stakeholders repute the organization and its activities as "inevitable and necessary" and the "acceptance is based on some broadly shared taken-for-granted assumptions" [20] (p. 72). It entails low chance of be influenced and managed by the organization, as it operates mainly in the subconscious of the constituencies. Therefore, a firm should simply adapt to social expectations, without trying to manipulate those stakeholders, as if the attempt is disclosed, the cognitive legitimacy would collapse [20], and they would start an active opposition to corporate's activities. It appears clear that moving from pragmatic to the moral to the cognitive, legitimacy become increasingly more difficult to manipulate, but it becomes also more stable once established [17].

Stakeholders perceive legitimate organizations as more worthy, meaningful, more predictable and more trustworthy [17]. Therefore, if an organization is perceived as non-legitimate it is likely to face several problems in the relationships with its stakeholders: customers may stop buying its products, suppliers may perceive the organization as non-trustworthy and cease to provide it the inputs; shareholders might withdraw their money; media and social activists group may decide to start promoting negative campaign and boycott of the companies' products; and local communities may decide not to concede to the company the possibility to operate there. Therefore, in order to survive, a corporation has to keep its legitimacy [22] [23].

However, it can happen at a given time, that corporate's behaviours differ from stakeholders' expectations. Here is when a legitimacy gap is likely to arise. Managers may strategically react to this according to how the hypothetical claim brought by a stakeholder is perceived as salient: if the stakeholder is considered as fundamental, the firm would react accommodating the request. However, if the stakeholder is considered as less important, the expectation may be ignored, and the company may decide not to take into consideration the threat or just to communicate symbolic engagement without taking significant steps into solving the problem [24].

According to Legitimacy theory, organizations try to prove that they are fulfilling the contract with society that allows them to carry out their business, and this contract implies that they operate in accordance with the values, limitations and norms of their respective society [25]. When a firm does not conform to society's norms a legitimacy gap arises putting a company's durability at risk [26] [27]. Organizations engage in informing their stakeholders about the consistency of their activities with the values shared by society, and they also try to influence the perception of their actual behavior to gain legitimacy [28]. The need for 
legitimacy may be more, or less, severe depending on a company's visibility [29].

Suchman [17] states that managers have constantly to monitor the external environment and stakeholders' expectations, without being too self-assured of the organization's legitimacy and the way of achieving it. For this reason, they should monitor multiple stakeholders' interest and perceive possible change, possibly involving stakeholders in the decision making of the firm. Moreover, companies should transform their legitimacy activities from episodic to continual, making the activities and the communication of the firm credible. In this way, "constituents tend to relax their vigilance" [21] and unexpected events that may threaten the legitimacy of the organization are likely to happen rarely.

Two main challenges can be identified:

- stakeholders, and therefore their interests, are heterogeneous [17].

- multinational companies operating in multiple countries may have to face different perceptions of legitimacy according to the country in which they are operating.

Some activities may be perceived as legitimate in the host country but not in the home country of the company, thus creating a dilemma in the firm on which activities to pursue and which not [30]. In order to deal with the first challenge, a company may decide to prioritize the interests of those stakeholders that are considered as more important. The second problem, however, requires a deeper analysis and balance of the different interests that stakeholders have in different countries, and if the risk of losing legitimacy is high, the firm should adopt the higher standards of CSR from the developed country and renounce to the benefits in term of lower costs that would arise adopting the lower standard from the developing country.

Much harder is the task of a company that has to repair its legitimacy. It happens when a legitimacy gap between societal expectations and corporate behaviour arose, and stakeholders threaten to withdraw firm's legitimacy. Some companies in the apparel sector had to face such issue, as their products were made in sweatshops. When this situation has become known by their stakeholders, a legitimacy crisis emerged.

One of the problems in this situation is that "legitimacy crises tend to become self-reinforcing" [17] stakeholders become suspicious about company's activities although the legitimacy gap has been closed, and the company is likely to be subjected to a high degree of pressure. Research provides evidence that visibility, in terms of size, business proximity to consumers and media exposure, expose companies to stakeholder pressure, and it affects their CSR activities and disclosure [31]-[37].

R. Q. How does stakeholders pressure shape a firm's engagement in CSR issues?

\section{Analysis of Nike's Case}

\subsection{Methodology}

In order to develop the analysis, we apply the "network theory of stakeholder in- 
fluences" of Rowley [38]. We made this choice because it allows to overcome the main shortcoming of Freeman's stakeholder map, namely the dyadic ties between the organization and its stakeholders. In fact, "since stakeholder relationships do not occur in a vacuum of dyadic ties" [38], we need a theory that allows us to get the relationships between stakeholders too.

Moreover, it adds some considerations and provides four strategies for managers in their interaction with the stakeholders, according to the level of network's density and the centrality of the company within the network.

Density is defined as the "measure of the relative number of ties in the network that link actors together" and, accordingly with literature [39], we calculated it as follows:

$$
\text { Density }=2 e / n(n-1)
$$

where: $e=$ number of ties; $n=$ number of nodes.

Finally, centrality refers to the company's position inside the network. It is possible to compute three kinds of centrality:

- Degree centrality, defined as "the number of ties he or she (the company) has with other actors in the network".

It is less useful than the other two types of centrality, being not relative to other stakeholders' ties. However, we are going to calculate it too in order to be as complete as possible.

- Closeness centrality measures "an actor's independent access to different points in the network" [38] and, consistently with literature [39], we determined it as follows:

$$
\text { Closeness Centrality }=(n-1) / \sum d G(v, t)
$$

- Betweenness centrality is defined by Freeman [40] as "the extent to which an actor has control over other actors' access to various regions of the network".

$$
\text { Betweenness Centrality }=\sum \sigma s t(v) / \sigma s t
$$

where: $n=$ number of nodes; $v=$ company's node; $t, s=$ other nodes; $d G(v, t)=$ shortest path between $v$ and $t$, $\sigma s t=$ number of shortest paths between $s$ and $t$; $\sigma s t(v)=$ number of shortest paths between $s$ and $t$ that pass-through $v$.

We make use of this structure considering three different moments: the first years of activity of the firm, when Nike's activity was basically of import and sale of the Onitsuka Tiger shoes; second, when the company decided to move the production to Third World countries but before media disclosure; and finally, after media disclosure of Nike's sweatshops in those countries and the appearance of a legitimacy gap.

\subsection{Nike's First Years}

Nike was born in 1964 from a graduate student at Stanford Business School called Phil Knight and Bill Bowerman, his former track coach at Oregon University [41].

In the beginning the name of the company was Blue Ribbon Sports, a name 
invented by Knight during its first trip to Japan, where he went to meet the executives of the Japanese company Onitsuka.

Knight has been really fascinated by the Onitsuka Tiger running shoes, which he thought could perform better than the more expensive shoes that were in the US market at that time and presented himself to the Japanese company as an importer from the United States.

During its first years, the company Blue Ribbon Sports was basically an importer from the Japanese company Onitsuka to sell shoes in the local market at a competitive price, thanks to the favourable exchange rate between Japan and United States. Blue Ribbon Sports was, until the early years of the 1970s a quite small company, with earnings being around \$1 million [41].

The stakeholders' network was not populated of many actors: the company almost did not have any direct impact on the natural environment nor relationships with the media; customers were running people and young students from the university; and the employees base was really small (Figure 1).

As it is possible to see in Table 1, the density of the network had the high value of 0.733 . This means that the company had a dense network, where stakeholders could exchange information between them, and are likely to impose their norms over the organization, thus leading to shared expectations within the stakeholders [38]. For example, during its early years Nike did not have the same contractual power it has now against its suppliers, that in the beginning was the Japanese company Onitsuka, nor it could abstain from seriously thinking on

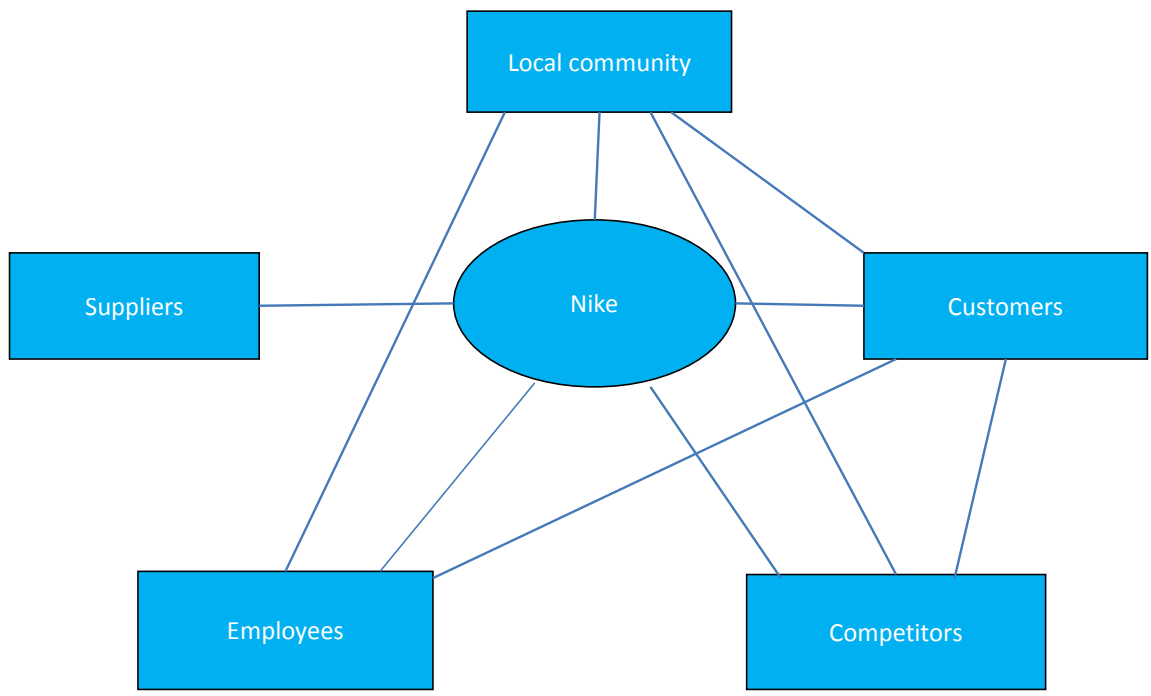

Figure 1. Stakeholder network during Nike’s first years. Source: Authors' elaborations.

Table 1. Density and centrality of Nike stakeholder network during its first years.

\begin{tabular}{cccccccc}
\hline Ties & $\begin{array}{c}\text { Total possible ties } \\
n(n-1) / 2\end{array}$ & Density & $\sum d G(v, t)$ & $\begin{array}{c}\text { Closeness } \\
\text { Centrality }\end{array}$ & ost $(v)$ & ost & $\begin{array}{c}\text { Betweenness } \\
\text { Centrality }\end{array}$ \\
\hline 11 & 15 & 0.733 & 5 & 1 & 1 & 10 & 0.1 \\
\hline
\end{tabular}

Source: Authors' calculations. 
how to handle each customer's complaint, due to the small number of customers the company had in the beginning.

Moreover, dense networks are likely to hinder firm's activities which goes against stakeholders' expectations, due to the possibility of coalition's formation between stakeholders and also to the fact that stakeholders are able to monitor the behaviour of the company.

Looking at closeness centrality, the value is 1 , suggesting a focal position of the organization, which means that the company can spread the information quickly, and it has been associated by Freeman with fewer message transmissions, shorter time and lower costs [11]. However, central organizations are more likely to resist stakeholder norms, due to their position which allows them to reach every stakeholder directly. Instead, betweenness centrality has a really low value suggesting that the other stakeholders of the network can communicate each other without the need to pass from the company.

According to Rowley [38], a dense network in which the company occupies a central position correspond to a situation of compromise, suggesting that Nike followed a strategy of negotiation with its stakeholders. Finally, degree centrality is equal to 5 , in fact Nike's node receives 5 ties from the other actors in the network. Degree centrality is a sort of influence's indicator, as the actor who receives more ties may be defined as prominent. Apart from the stakeholders previously mentioned, it is possible to find also government, which dictates the laws and has, as a stake, that companies pay taxes and treats fairly the local community and its employees; local communities where Nike established its business, mainly Oregon and California; and competitors.

\subsection{Nike's Activity during the Period 1970-1990}

In the early 1970s the company changed its strategy and started designing a new line of shoes that was called Nike. However, for doing so they needed cash, which arrived from the sale of $35 \%$ of the company to investors [41].

In the beginning of the 1970, Blue Ribbon Sports outsourced the production to two Japanese shoe manufacturers and opened up its own factories in Maine and New Hampshire. However, the company has soon to close those factories due to the high costs of production in the United States. The same happened with the providers in Japan: as the country developed, the costs rose, the labour market become tighter and the exchange ratio between dollar and yen was not as convenient as before due to the economic measures undertaken by the President of the United States Richard Nixon, who abolished the direct convertibility of the dollar into gold, causing a devaluation of the dollar against other currencies. For these reasons, Blue Ribbon Sports started looking around in search of new countries, with cheap and flexible labour market, where outsourcing the production of shoes. The countries that were chosen are: China, Korea, Taiwan (Republic of China) and Thailand.

Although the Nike shoe line was launched in 1971-1972, the company changed its name from Blue Ribbon Sports to Nike just in 1978. Nike's strategy has been 
from the beginning to look for the cheapest place where to move the production, and the same that happened in Japan and in the United States, happened after with the factories in Korea and in Taiwan (Republic of China). As the costs in these two countries started to rise, the company moved the production to cheaper countries, such as Vietnam and Indonesia. However, this strategy may have drawbacks too: one of this is the charge of looking for factories which pay low wages and have poor working conditions, thus undermining the reputation of the company and to pose legitimacy at risk. This kind of critics against Nike started around the 1980s, and grew exponentially in the 1990s, when Nike has been overwhelmed by a wave of criticisms. The first proof of child labour in one of Nike's factories will appear in 1996 in Bangladesh [42]. Before these years, there is not any media reportage about child labour, but it makes sense to think that this plague was already present in the factories where Nike and other companies outsourced the production. For these reasons, in the analysis of the stakeholder network for the period 1970-1990 we have added children too, but not media, as such phenomenon was not yet disclosed by them.

As reported by Suchman [17], legitimacy is a perception or assumption: Nike departed from societal norms, but it still retained legitimacy as the departure goes unnoticed by the society. Stakeholders were not aware of what was happening in Nike's subcontractors until media disclosed the situation. Moreover, the legitimacy claim, in this situation, was brought only by children and workers in the sweatshops, which in that moment were not salient stakeholders for the company, thus making their claims not relevant for Nike, which decided to adopt the strategy of ignoring them.

Looking at the chart (Figure 2), the main stakeholders of Nike were: shareholders, as Nike went public in 1980 with $50 \%$ of the market share in the US athletic shoe market; customers, who were now not just athletes but rather normal people who do not even used the shoes for doing sport; employees, who were now distributed around the world; competitors, mainly Adidas and Reebok; natural environment, that started to deserve attention as Nike's activity and production have grown; suppliers, who were factories in the Third World countries with low wages and poor working conditions; and finally children (and all the workers from the providers of Nike products) who are not directly connected with Nike, as they do not have contact with the company, nor even know what Nike is.

As reported in Table 2, Nike faced a stakeholder network with a density value of 0.46 a value certainly lower than that one of the first years of Nike's activities. This means that the company increased its power over the stakeholders, being able to impose its norms. In fact, looking for cheap factories where outsource the production, Nike's contractual power was immensely higher than that one of its providers, making the company able to enforce prices, quantity and time of production. The closeness centrality of Nike was not as high as in the beginning, now it is 0.8 that is a still high value. This is due to the fact that children do not 


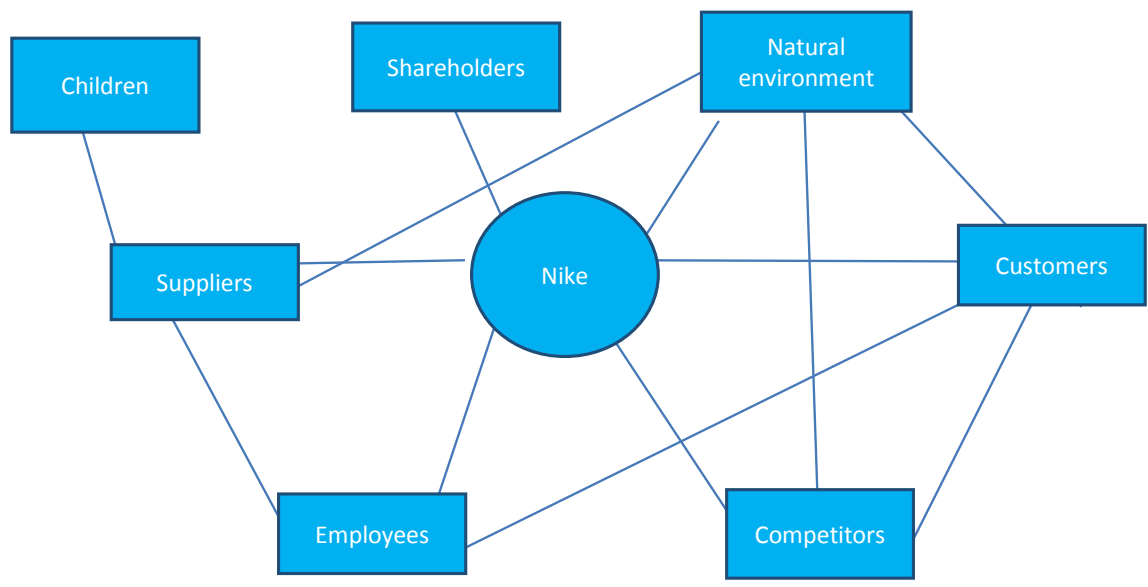

Figure 2. Stakeholder network during the period 1970-1990. Source: Authors' elaborations.

Table 2. Density and centrality of Nike stakeholder network during the period 1970-1990.

\begin{tabular}{cccccccc}
\hline Ties & $\begin{array}{c}\text { Total possible ties } \\
n(n-1) / 2\end{array}$ & Density & $\sum d G(v, t)$ & $\begin{array}{c}\text { Closeness } \\
\text { Centrality }\end{array}$ & ost $(v)$ & ost & $\begin{array}{c}\text { Betweenness } \\
\text { Centrality }\end{array}$ \\
\hline 13 & 28 & 0.46 & 8 & 0.875 & 6 & 21 & 0.286 \\
\hline
\end{tabular}

Source: Authors' calculations.

have direct communication with the company, and probably even do not know what Nike is, and are forced to pass through Nike's suppliers if they want to communicate with the company. Looking at the betweeness centrality now the value is 0.286 which is higher than the previous value as Nike have more ability to control the information flows across the network. Degree centrality is equal to 6 , as Nike has one more tie, namely that one with shareholders. Rowley identifies low density and high centrality with a position of commander, and it is confirmed by the fact that before media disclosure, Nike did not face any campaign of boycott, nor significant problem in the relation with its stakeholders. In low dense network, stakeholders are less able to coordinate each other and unify against the behaviour of a company, becoming in this way passive [17].

\subsection{From the 1990s until Now}

The 1990s has been the period in which Nike has received more critics about the working conditions in the factories where the company outsourced its production.

Chronologically, Nike has been accused of child labour for the first time in 1996, when the magazine Life published an article on this issue with a photo of a Pakistan 12-years boy sewing a Nike soccer ball [43], and following the ILO report, it confirmed the employment of children by local employers. Successively, in October 2000, the BBC program Panorama interviewed several underage workers in Cambodia, which made clothes for Nike and Gap. In the beginning, Nike's executives adopted a behaviour of indifference in front of these critics. 
They said that the company was not the owner of those factories, so the company did not have a legal responsibility on what happened there. In the beginning, Nike did not think that a company has an ethical responsibility too, and it is possible to cite two situations as examples. The first one is a conversation between Michael Moore and Phil Knight about the documentary film of Moore called "The Big One":

Moore: "twelve years old working in factories, that's okay for you?

Knight: "They're not 12-years old. The minimum age is 14 ."

Moore: "How about 14, then? Doesn't that bother you?"

Knight: "No." [44].

As it is possible to see, the only concern of the CEO of Nike was to follow the rules of the countries in which the company outsourced the production, without taking into consideration any ethical issue. Another evidence of this, is what Nike's general manager in Jakarta argued about low wages and poor working conditions in Indonesian factories that produced for Nike: "They are our subcontractors. It's not within our scope to investigate" [45]. Therefore, Nike thought they did not have to monitor what was happening in the factories of its providers, and because Nike did not own those factories, it was careless about the situation. However, very soon the company changed its strategy and its approach toward these issues, due to the surge of critics and boycott from social activist groups and pressure from the media. During a speech in 1998 at the National Press Club, Knight argued that: "the Nike product has become synonymous with slave wages, forced overtime, and arbitrary abuse" [42].

According to Maria Eitel, Vice President and Senior Advisor for Corporate Responsibility at Nike, the disclosure by media of children' employment in Pakistan factories represented a "critical event for the company in terms of its understanding of globalization, international labour standards, and corporate responsibility" [42]. Soon, Nike realized that a legitimacy gap between its activities and societal values was arising, and the company has to do its best to close the gap and repair its legitimacy. Now, in fact, the legitimacy claim is brought by the society as a whole, and children are salient stakeholders too for the company, having all the three attributes of legitimacy, power and urgency thanks to media disclosure. For this reason, from this time until now, Nike is adopting a series of measures in order to repair its legitimacy and to be, or to appear to be, a more socially responsible company.

Such measures include an increased level of suppliers' monitoring; relations with International and Non-Profit Multi-Stakeholder Organizations such as the UN Global Compact and the Fair Labor Association; new departments that deal with sustainability issues such as environment and labour practices; and the increasing of the minimum age for workers in Nike factories to 18 years old in footwear factories and 16 years old in apparel factories [43].

Repairing legitimacy is a much hardier task than maintaining it, especially because of the higher degree of stakeholders' scrutiny a company will have to 
face for a long time. Trying to manipulate stakeholders through communication channels may be highly dangerous, as if stakeholders become aware of this may decide to withdraw definitely the company's legitimacy. Looking at the stakeholder network, it presents the same situation as in the 1970-1990 period but with two important new actors: media and social activist groups. As seen, media has had the fundamental role of disclosing the operations in Third World factories from where many companies in developed countries outsourced the production of its products. By itself, outsourcing is a legitimate strategy; however, it should be done in an ethical way, with constant monitoring of the providers. Unfortunately, most of the time outsourcing results in an extreme imbalance in the contractual power between the parts, with firms in developed countries imposing really low prices to their subcontractors without possibility of negotiations, thus leading providers to be forced, in order to compete with others, to hire workforce as cheap as possible, with children being surely the cheapest. Moreover, companies often impose very strict timing and quantity of production to their suppliers, thus leading to stressful working days for the employees in the factories. As an example, we can cite some providers of Nike that have adopted a salary system in which workers receive their full-day's pay only if they meet their work quota, leading them, if the requirement is not met, to work more in order to receive the standard pay [43]. Actually, companies are undertaking measures to improve the situations, such as monitoring programs that can be done by the company itself or by third-part auditors.

Another new actor of the network is social activist groups (Figure 3). People and organizations started by the 1990s to promote boycotts of Nike's products, and the most important among them was the Anti-sweatshop movement.

Following the stakeholder theory, a company should engage in a positive exchange of information and communication with all its stakeholders, and not just the shareholders. While in the beginning Nike seemed to follow a different strategy,

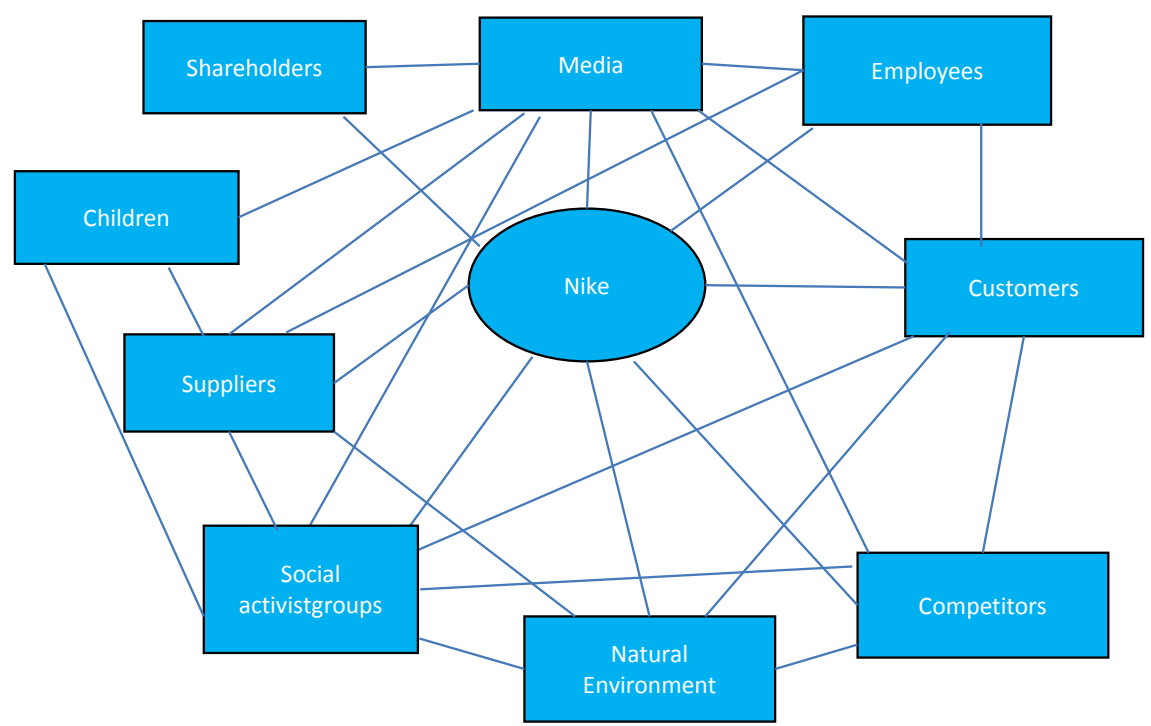

Figure 3. Stakeholder Network from the 1990s until now. Source: Authors' elaborations. 
not taking care of the critics it receives from media, customers, and pressure groups, it has to change soon its strategy, promising to consider ethical issues too. Another evidence that stakeholders do matter, and that companies have responsibilities in dealing with them, is what happened in 1997 in Vietnam.

The audit firm Ernst and Young audited a Nike subcontractor in Vietnam and found that "toluene" (chemical solvent) concentrations exceeded between 6 and 177 times the acceptable standards in certain sections of the plant", adding that "chemical releases had causes numerous cases of skin and heart disease, and that respiratory ailments, due to excess dust, were rampant in other areas of the factory" [42] (p. 13).

This episode has been considered very damaging for Nike reputations, first of all because the audit firm was hired by Nike to audit its suppliers' factories, and secondly because Nike explained in its report that it has adopted measures to solve the problems in the sweatshops, but it did not disclose the problems that the audit firm found in the Vietnamese factor. Mark Kasky, who called himself a "corporate referee" judged this issue as "false advertising" and filed in 1998 a lawsuit against Nike. Nike appealed on the First Amendment protection, helped by the limited definition of commercial speech, namely a speech that does "no more than propose a commercial transaction" [46]. The case concluded in 2003 without official sentences, as Nike made a charity settlement with Kasky, giving $\$ 1.5$ million over the next 3 years to the Fair Labor Association, which monitors labour standards.

This means that companies are accountable for transparency in the disclosure of CSR information with respect to their stakeholders. In the disclosure moment, the density of the network increased again, at a value of 0.6 (Table 3) which means that Nike lost some of the power it had acquired. However, the network is still less dense than in the first years of activity of the company. The closeness centrality of the company is on a very similar level of that one of the 1970-1990 period, and the betweenness centrality is near to zero. Degree centrality is now equal to 8 , as it is augmented the number of stakeholders directly tied with Nike, which is reflected by a bigger network too.

As it is possible to see (Table 3), there are some differences in the stakeholders' network in which Nike operates: it is denser than before but still less than the first years of activity, because of the increased number of nodes. Also, the company is no longer able to be the gatekeeper of the information' flows within the network, being its betweenness centrality close to zero. Therefore, Nike is in a position in which it has to negotiate with its stakeholders. Both the company and the stakeholders are able to impact each other, with Nike having to

Table 3. Density and centrality of Nike stakeholder network from 1990 until now.

\begin{tabular}{cccccccc}
\hline Ties & $\begin{array}{c}\text { Total possible ties } \\
n(n-1) / 2\end{array}$ & Density & $\sum d G(v, t)$ & $\begin{array}{c}\text { Closeness } \\
\text { Centrality }\end{array}$ & ost $(v)$ & ost & $\begin{array}{c}\text { Betweenness } \\
\text { Centrality }\end{array}$ \\
\hline 27 & 45 & 0.60 & 10 & 0.9 & 1 & 36 & 0.028 \\
\hline
\end{tabular}

Source: Authors' calculations. 
face an uncertain environment, and its stakeholders that may build solid link between them and may influence corporate behaviour. In this situation Nike had to adopt measures in order to re-establish its reputation and credibility within the network, such as improving monitoring program and adopting stricter labour standards.

Although there are no doubts about the increased engagement of Nike in trying to solve the sweatshop issue, there is still some doubt on the effectiveness of the adopted measures. For example, although Nike promised commitment in coping with child labour, in 2000 the BBC program Panorama showed that it was still a reality in factories where Nike outsourced its products. So, the legitimate question is: how is it possible that such a situation was discovered by media and not by the monitoring programs that Nike have adopted? However, it is true that child labour is a plague difficult to completely solve: due to the situation in those countries, children are forced to work and sometimes have false document in order to get a job, thus making the discovery of the phenomenon more complex.

The most effective solution may be to grant parents who work in those factories with a living wage, as established by the Worker Rights Consortium (WRC), an independent labour right monitoring organization. This view opposed the concept of minimum wage, which is promoted by other monitoring organizations such as the Fair Labor Association (FLA). In this way parents receive a salary that allow them to take care of themselves and their families, children included, meeting their basic needs.

Unfortunately, Nike has always refused to apply the standards of the WRC, while accepting to monitor its subcontractors making sure that in those factories the employees receive the minimum wage or the local industry standard if higher (Workplace code of Conduct, FLA). Nike's reasons have been mainly two: first of all, there is not a globally accepted definition of living wage and second, legal wage is fairly enough for a worker in order to meet the basic need of him and his family.

About the first point, although it may be true that a definition of living wage is difficult to quantify in economic terms, Nike could engage in positive conversations with the stakeholders involved in the issue, such as workers, labour-right organizations and expertise and come to an agreement about how much a living wage may be.

The second reason is definitely weaker than the first and has been demonstrated as false. First of all, because it is known that many developing countries impose really low minimum wages in order to attract foreign investments; and second, because there are empirical evidences suggesting that minimum wages are often not enough to meet basic needs [47]. On the other hand, from December 2016 until last summer, Nike has suffered the threat of a return to the sweatshop problem [8] [9], relating to protest demonstrations by students against sweatshops. In December Georgetown students took part in a sit-in in the office of the president as they wanted the university to end its licensing agreement with 
Nike at the end of 2016, as it was expiring for that period. One of the most important reasons was that Nike would not allow the Worker Rights Consortium (WRC) to enter its factories. So, Georgetown did not renew the contract, that is, the supply of Nike branded clothing. On August 30, Georgetown University and Nike signed a new licensing agreement that implied access for WRC to Nike supplier factories producing university-licensed products, in order to carry out inspections on working conditions [10].

\section{Discussion}

This analysis of the stakeholder network of Nike during its history, has been useful in order to highlight and reinforce at least four points that have to be taken in mind when considering the legitimacy theory and the stakeholder theory and approach:

The first point is that before media disclosure, Nike's departure from societal norms and values went unnoticed so the company was able to retain its legitimacy. The legitimacy claim was brought only by exploited children and workers in the Third World factories; however, they lacked the attributes to be considered salient stakeholders by the company, thus making their claims unheard. When media disclosed the operation of the company in the Third World countries, society became aware of the departure of Nike from their beliefs and a legitimacy gap arose. As reported by Suchman [17] (p. 598), in order to repair company's legitimacy, managers "may attempt to deny the problem ... unfortunately, unless such denials are sincere, subsequent relevations may severely deplete the organization's long-term legitimacy reserves". Actually, Nike's denials can be considered as sincere: the company was not the owner of the factory in the Third World countries. However, Nike failed to understand the changing dynamic of the external environment. Stakeholders expectations were changed, as they reputed a company's responsibility to monitor what was happening in the suppliers' factories, exactly as if the company was the owner of those factories. Nike soon realize that it was losing its legitimacy and changed the strategy: instead of denying the problem, it recognized it and engaged in a proactive approach, participating in multiple initiatives and associations, adopting standards and code of conducts, and so on. However, due to the unethical behaviour adopted in the past and its high visibility, Nike is still the target of social activists and media scrutiny much more than other companies, thus confirming that repairing legitimacy is much more difficult than maintaining it.

The second point is that there are cases in which companies must "go beyond the law" and follow a strategy based on ethical responsibility. Nike and its sweatshops, along with the issue of child labour, are clear examples of a situation in which a company has to adopt a proactive behaviour with respect to the problem, although if it could be considered legal to avoid such approach. Such consideration is based on normative ground, but as it has been showed previously, there are also economic reasons. Nike in the beginning adopted an indifferent attitude about the sweatshops issue, but soon it has been forced to deal 
with it actively, as media and social activist groups (and the society all) expressively asked to do so. Not taking into consideration the society expectations and keeping a passive behaviour may have cost to the company an extremely greater amount of resources due to bad reputation. Moreover, sustainable supply chain management may actively shape a firm's reputation as a "good citizen" as it may be perceived not as a mere reaction to stakeholders' pressure [48]. In fact, literature points out the role of CSR in building a company's reputation [49] [50] [51] [52], and in this way CSR commitment affects performance [53] [54] and market valuation [55].

The third is the effect of media pressure. Media, by disclosing corporate activities, can force companies to handle the new situation that has been reported. As it is possible to see, the situation of Nike was very different before and after media disclosure of the sweatshops in the Third World countries. Before it, the stakeholder network was less dense, with the company in a central position able to enforce its norms over the stakeholders. The flow of information about what was happening in the factories of Nike's subcontractors was hindered by the fact that there was not any actor, if not Nike, to be directly connected to them, and that it could therefore exchange information to other stakeholders in the network. This role has been taken later by the media who, thanks to their direct relationship with Nike's suppliers have been able to report about the working conditions in those factories. The consequences of this have been very grave for Nike, as customers driven by activist groups started promoting boycott of the company's products, thus seriously threatening Nike reputation. The role of media and the free flow of information is something that companies have to deal with, trying to take advantage of it.

The legitimacy framework explains the role that communication has for companies in doing so. Companies that are neither transparent nor accountable to their stakeholders will be overwhelmed by the new communication technologies, thus posing their legitimacy at risk.

The fourth point is the dynamic nature of the stakeholders and legitimacy concept. Actors who before were not considered as stakeholders of Nike, or with whom Nike had not relations, such as media and social activist groups, then have become influential and the company had to take them into consideration, thus demonstrating that actors who are not actually stakeholders or not worthy of attention, may be so in the future.

This case highlights the feasibility of the stakeholders' definition made by Mitchell et al. [12] that classified them according to their attributes, saying that stakeholder's possession of attributes may vary over time. An example of this are children who worked in the factories where Nike outsourced the production, who while in the beginning had only legitimate claims, then they acquired urgency and even power through their relationship with media and social activist groups.

Another example are media and social activist groups who before disclosure did not deserve attention by the company, but after they acquired power and le- 
gitimacy, thus becoming dominant stakeholders.

Legitimacy is a dynamic concept too: before disclosure Nike has its legitimacy intact; however, as it has been shown, this situation is not permanent, and the company has to carefully monitor stakeholders' expectations and the external environment if it wants to avoid a legitimacy gap to arise.

The main shortcoming of the network perspective is that because of the great number of stakeholders within the network of a company, it is difficult to be able to represent the network in a clear way. For this reason, we faced the challenge to decide which stakeholders to represent and which to leave out of the analysis. The two most important actors who are not in the analysis are government and local communities. Regarding the first, due to globalization and outsourcing of production, governments are seeing their power to greatly decrease in front of the companies, which are increasingly deciding to adopt voluntary codes of conduct and standards of behaviour in order to fill the public regulation's gap. For the same reasons, namely globalization and outsourcing, local communities too are losing their power and have almost any relationship with companies, especially in case of multinationals such as Nike.

\section{Conclusions}

The story of Nike confirms that the need for legitimacy does work in influencing corporates' decisions, as when a legitimacy gap between society's expectations and firm's operations emerged Nike changed its strategy from a denial of the responsibilities to a proactive approach in social issues.

While in the beginning the network of Nike was not composed of many stakeholders, as the company started to move its operation internationally, its visibility increases. However, it is only in the 1990s when media disclosed the poor working condition and the employment of children in Nike's supplier factories. From that moment, a legitimacy gap arose between societal expectations and company's activities. Although it was not a legal responsibility of Nike to check suppliers' sweatshops, society expected Nike to go beyond what established by the law and to commit to ethical responsibilities too. Stakeholders started organizing themselves against Nike's operations, thanks to the help of media and social activist groups. Even if in the beginning Nike denied any responsibility, as it saw its legitimacy and reputation at risk, it started to adopt measures for solving the problem.

This analysis highlights some important points. First of all, it is possible to notice clearly the moment when the legitimacy gap arose, and the different responses of Nike, from denying responsibilities to engaging in proactive behaviors. The case highlights the dynamic nature of stakeholders and legitimacy, and it underlines the importance of two actors which are rarely considered as primary and most important stakeholders, namely media and social activist groups. It confirms that as visibility increases, the company is likely to become an easier target of criticisms and stakeholders' scrutiny, and it highlights the influence and 
power that media can have on an organization. This suggests that either if we want to consider them as stakeholders or if we do not-as Donaldson and Preston [56] who defined media as influencers who do not have a stake in the company-managers must be well aware of the potential negative or positive impact they can have. This paper focuses on a single sector that is characterized by a strong proximity to consumers. Consumers are stakeholders in various ways because they are interested in a firm's behavior in terms of a product safety and quality as well as in terms of a product social and environmental impact. So, it could be of interest to deepen the study of media pressure on a firm's social and environmental engagement taking analyzing cases of firms operating in industry that are not characterized by consumer's proximity.

\section{Conflicts of Interest}

The authors declare no conflicts of interest regarding the publication of this paper.

\section{References}

[1] Buchholtz, A.K. and Carroll, A.B. (2012) Business and Society: Ethics and Stakeholder Management. CENGAGE Learning., Canada.

[2] Dowling, J. and Pfeffer, J. (1975) Organizational Legitimacy: Social Values and Organizational Behaviour. The Pacific Sociological Review, 18, 122-136. https://doi.org/10.2307/1388226

[3] Pomering, A. and Dolnicar, S. (2009) Assessing the Prerequisite of Successful CSR Implementation: Are Consumers Aware of CSR Initiatives? Journal of Business Ethics, 85, 285-301. https://doi.org/10.1007/s10551-008-9729-9

[4] Brown, T.J. and Dacin, P.A. (1997) The Company and the Product: Corporate Associations and Consumer Product Responses. The Journal of Marketing, 61, 68-84. https://doi.org/10.1177/002224299706100106

[5] Morsing, M. and Schultz, M. (2006) Corporate Social Responsibility Communication: Stakeholder Information, Response and Involvement Strategies. Business Ethics: A European Review, 15, 323-338.

https://doi.org/10.1111/j.1467-8608.2006.00460.x

[6] Times (2018).

https://www.ft.com/content/e427327e-5892-11e8-b8b2-d6ceb45fa9d0

[7] New York Times (2018). https://www.nytimes.com/2018/09/20/fashion/italy-luxury-shadow-economy.html

[8] Fastcompany (2018). https://www.fastcompany.com/40460462/heres-how-georgetown-convinced-nike-to -make-a-major-concession-on-workers-rights

[9] Quartz (2018). https://qz.com/1042298/nike-is-facing-a-new-wave-of-anti-sweatshop-protests/

[10] Maquila Solidarity Network (2018). http://www.maquilasolidarity.org/en/nike-signs-agreement-cooperate-wrc-factory-i nspections-september-2017

[11] Freeman, R.E. (1984) Strategic Management: A Stakeholder Approach. Pitman, Boston. 
[12] Mitchell, R.K., Agle, B.R. and Wood, D.J. (1997) Toward a Theory of Stakeholder Identification and Salience: Defining the Principle of Who and What Really Counts. Academy of Management Review, 22, 853-886. https://doi.org/10.5465/amr.1997.9711022105

[13] Deegan, C. (2002) Introduction: The Legitimising Effect of Social and Environmental Disclosures-A Theoretical Foundation. Accounting. Auditing \& Accountability Journal, 15, 282-311. https://doi.org/10.1108/09513570210435852

[14] Haniffa, R.M. and Cooke, T.E. (2005) The Impact of Culture and Governance on Corporate Social Reporting. Journal of Accounting and Public Policy, 24, 391-430. https://doi.org/10.1016/j.jaccpubpol.2005.06.001

[15] Ellerup Nielsen, A. and Thomsen, C. (2007) Reporting CSR - What and How to Say It? Corporate Communications: An International Journal, 12, 25-40. ttps://doi.org/10.1108/13563280710723732

[16] Gray, R., Kouhy, R. and Lavers, S. (1995) Corporate Social and Environmental Reporting: A Review of the Literature and a Longitudinal Study of UK Disclosure. Accounting, Auditing \& Accountability Journal, 8, 47-77. https://doi.org/10.1108/09513579510146996

[17] Suchman, M. (1995) Managing Legitimacy: Strategic and Institutional Approaches. The Academy of Management Review, 20, 571-610. https://doi.org/10.5465/amr.1995.9508080331

[18] Clarkson, M.E. (1995) A Stakeholder Framework for Analyzing and Evaluating Corporate Social Performance. Academy of Management Review, 20, 92-117. https://doi.org/10.5465/amr.1995.9503271994

[19] Wood, D.J. (1991) Corporate Social Performance Revisited. The Academy of Management Review, 16, 691-718. https://doi.org/10.5465/amr.1991.4279616

[20] Palazzo, G. and Scherer, A.G. (2006) Corporate Legitimacy as Deliberation: A Communicative Framework. Journal of Business Ethics, 66, 71-88. https://doi.org/10.1007/s10551-006-9044-2

[21] Ashforth, B.E. and Gibbs, B.W. (1990) The Double-Edge of Organizational Legitimation. Organization Science, 1, 177-194. https://doi.org/10.1287/orsc.1.2.177

[22] Husted, B.W. (1998) Organizational Justice and the Management of Stakeholder Relations. Journal of Business Ethics, 17, 643-651.

[23] Branco, M.C. and Lima Rodrigues, L. (2006) Communication of Corporate Social Responsibility by Portuguese Banks: A Legitimacy Theory Perspective. Corporate Communications: An International Journal, 11, 232-248. https://doi.org/10.1108/13563280610680821

[24] De Villiers, C. and Van Staden, C.J. (2006) Can Less Environmental Disclosure Have a Legitimising Effect? Evidence from Africa. Accounting, Organizations and Society, 31, 763-781. https://doi.org/10.1016/j.aos.2006.03.001

[25] Brown, N. and Deegan, C. (1998) The Public Disclosure of Environmental Performance Information-A Dual Test of Media Agenda Setting Theory and Legitimacy Theory. Accounting and Business Research, 29, 21-41. https://doi.org/10.1080/00014788.1998.9729564

[26] Sethi, S. (1975) Dimensions of Corporate Social Performance: An Analytical Framework. California Management Review, 17, 58-64. https://doi.org/10.2307/41162149

[27] Oliver, C. (1991) Strategic Responses to Institutional Processes. Academy of Management Review, 16, 145-179. https://doi.org/10.5465/amr.1991.4279002 
[28] Lindblom, C.K. (1994) The Implications of Organizational Legitimacy for Corporate Social Performance and Disclosure. Critical Perspectives on Accounting Conference, New York.

[29] Gavana, G., Gottardo, P. And Moisello, A.M. (2017) Sustainability Reporting in Family Firms: A Panel Data Analysis. Sustainability, 9, 38. https://doi.org/10.3390/su9010038

[30] Barkemeyer, R. (2007) Legitimacy as a Key Driver and Determinant of CSR in Developing Countries. The 2007 Marie Curie Summer School on Earth System Governance, Amsterdam, 24 May-6 June 2007.

[31] Belkaoui, A. and Karpik, P.G. (1989) Determinants of the Corporate Decision to Disclose Social Information. Accounting, Auditing \& Accountability Journal, 2, 26-31. https://doi.org/10.1108/09513578910132240

[32] Branco, M.C. and Rodrigues, L.L. (2008) Factors Influencing Social Responsibility Disclosure by Portuguese Companies. Journal of Business Ethics, 83, 685-701. https://doi.org/10.1007/s10551-007-9658-Z

[33] Cowen, S.S., Ferreri, L.B. and Parker, L.D. (1987) The Impact of Corporate Characteristics on Social Responsibility Disclosure: A Typology and Frequency-Based Analysis. Accounting, Organizations and Society, 12, 111-122. https://doi.org/10.1016/0361-3682(87)90001-8

[34] Hackston, D. and Milne, M.J. (1996) Some Determinants of Social and Environmental Disclosures in New Zealand Companies. Accounting, Auditing \& Accountability Journal, 9, 77-108. https://doi.org/10.1108/09513579610109987

[35] Patten, D.M. (1991) Exposure, Legitimacy, and Social Disclosure. Journal of Accounting and Public Policy, 10, 297-308. https://doi.org/10.1016/0278-4254(91)90003-3

[36] Gamerschlag, R., Möller, K. and Verbeeten, F. (2011) Determinants of Voluntary CSR Disclosure: Empirical Evidence from Germany. Review of Managerial Science, 5, 233-262. https://doi.org/10.1007/s11846-010-0052-3

[37] Lucchini, A. and Moisello, A.M. (2017) CSR Disclosure, Visibility and Media Pressure International Evidence from the Apparel and Textile Industry. European Journal of Economics, Finance and Administrative Sciences, 93, 5-28.

[38] Rowley, T.J. (1997) Moving beyond Dyadic Ties: A Network Theory of Stakeholder Influences. Academy of Management Review, 22, 887-910. https://doi.org/10.5465/amr.1997.9711022107

[39] Wasserman, S. and Faust, K. (1994) Social Network Analysis: Methods and Applications. Vol. 8, Cambridge University Press, Cambridge. https://doi.org/10.1017/CBO9780511815478

[40] Freeman, L.C. (1978) Centrality in Social Networks Conceptual Clarification. Social Networks, 1, 215-239. https://doi.org/10.1016/0378-8733(78)90021-7

[41] Frisch, A. (2008) Built for Success: The Story of Nike. Creative Education, Minnesota, 5-14.

[42] Locke, R.M. (2003) The Promise and Perils of Globalization: The Case of Nike. Management: Inventing and Delivering Its Future, 39, 40.

[43] Connor, T. Still Waiting for Nike to Do It: Nike's Labour Practices in the Three Years since CEO Phil Knight's Speech to the National Press Club. http://www.globalexchange.org/campaigns/sweatshops/nike/stillwaiting.html

[44] Boje, D.M. and Khan, F.R. (2009) Story-Branding by Empire Entrepreneurs: Nike, Child Labor, and Pakistan's Soccer Ball Industry. Journal of Small Business \& En- 
trepreneurship, 22, 9-24. https://doi.org/10.1080/08276331.2009.10593439

[45] Rosenzweig, P.M. (1994) International Sourcing in Athlete Footwear: Nike and Reebok. Harvard Business School Case 9-394-189, 6.

[46] DeTienne, K.B. and Lewis, L.W. (2005) The Pragmatic and Ethical Barriers to Corporate Social Responsibility Disclosure: The Nike Case. Journal of Business Ethics, 60, 359-376. https://doi.org/10.1007/s10551-005-0869-x

[47] Luce, S. (2017) Living Wages: A US Perspective. Employee Relations, 39, 863-874. https://doi.org/10.1108/ER-07-2017-0153

[48] Wolf, J. (2014) The Relationship between Sustainable Supply Chain Management, Stakeholder Pressure and Corporate Sustainability Performance. Journal of Business Ethics, 119, 317-328. https://doi.org/10.1007/s10551-012-1603-0

[49] Gallego-Alvarez, I., Prado-Lorenzo, J.M., Rodríguez-Domínguez, L. and García-Sánchez, I.M. (2010) Are Social and Environmental Practices a Marketing Tool? Empirical Evidence for the Biggest European Companies. Management Decision, 48, 1440-1455. https://doi.org/10.1108/00251741011090261

[50] Brammer, S. and Pavelin, S. (2004) Building a Good Reputation. European Management Journal, 22, 704-713. https://doi.org/10.1016/j.emj.2004.09.033

[51] Toms, J.S. (2002) Firm Resources, Quality Signals and the Determinants of Corporate Environmental Reputation: Some UK Evidence. The British Accounting Review, 34, 257-282. https://doi.org/10.1006/bare.2002.0211

[52] Fombrun, C. and Shanley, M. (1990) What's in a Name? Reputation Building and Corporate Strategy. Academy of Management Journal, 33, 233-258.

[53] Gavana, G., Gottardo, P. and Moisello, A.M. (2018) Do Customers Value CSR Disclosure? Evidence from Italian Family and Non-Family Firms. Sustainability, 10 1642.

[54] Paul, C.J. and Siegel, D.S. (2006) Corporate Social Responsibility and Economic Performance. Journal of Productivity Analysis, 26, 207-211. https://doi.org/10.1007/s11123-006-0016-4

[55] Nekhili, M., Nagati, H., Chtioui, T. and Rebolledo, C. (2017) Corporate Social Responsibility Disclosure and Market Value: Family versus Nonfamily Firms. Journal of Business Research, 77, 41-52. https://doi.org/10.1016/j.jbusres.2017.04.001

[56] Donaldson, T. and Preston, L.E. (1995) The Stakeholder Theory of the Corporation: Concepts, Evidence, and Implications. Academy of Management Review, 20, 65-91. https://doi.org/10.5465/amr.1995.9503271992 